\title{
VOLUMETRIC MODELING OF Pinus taeda L. FROM ORBITAL IMAGES
}

\author{
MODELAGEM VOLUMÉTRICA DE Pinus taeda L. A PARTIR DE IMAGENS ORBITAIS \\ Carla Talita Pertille ${ }^{1}$, Marcos Felipe Nicoletti ${ }^{2}$ \\ 1,2 Universidade do Estado de Santa Catarina, Lages, Santa Catarina, Brasil, - carlatpertille@gmail.com \\ \&marcos.nicoletti@udesc.br
}

\begin{abstract}
This work aimed to investigate the potential of image-derived indices derived from Sentinel-2/MSI images in the volumetric modeling of a stand of Pinus taeda L. located in Bom Retiro, State of Santa Catarina. For this purpose, field data derived from a forest inventory were used, by the fixed area method and simple random sampling with an allocation of 18 circular plots of $400 \mathrm{~m}^{2}$. The remotely located data comprised an orbital image from the Sentinel$2 / \mathrm{MSI}$ sensor. From this image, 14 average vegetation indices per plot were calculated. These indices were correlated with the volume by plot $\left(\mathrm{m}^{3} 0.04 \mathrm{ha}^{-1}\right)$ derived from the inventory. The indices with the best correlation for volume by plot $\left(\mathrm{m}^{3} 0.04 \mathrm{ha}^{-1}\right)$ were the Generalized Difference Vegetation Index (GDVI) and Adjusted Soil Vegetation Index (SAVI) with 0.39 and 0.36 , respectively. The best regression model completed using these Vls estimated the volume by plot with $\mathrm{R}^{2}$ controls of 0.9402 and Syx of $1.44 \%$. The use of spectral indices generated from Sentinel-2/MSI sensor data enabled the volumetric estimate of the Pinus taeda $\mathrm{L}$. stand, not revealing differences between the volume accumulated by forest inventory and by orbital images. However, it is worth pointing out that new tests be carried out on other forest species and with medium to high spatial resolution sensors.
\end{abstract}

KEYWORDS: Remote sensing, Stepwise, Vegetation index.

RESUMO

Este trabalho objetivou investigar o potencial de índices de vegetação derivados de imagens Sentinel-2/MSI na modelagem volumétrica de um povoamento de Pinus taeda L. localizado em Bom Retiro, Santa Catarina. Para tanto, foram utilizados dados de campo de um inventário florestal, pelo método de área fixa e amostragem aleatória simples com a alocação de 18 parcelas circulares de $400 \mathrm{~m}^{2}$. Os dados remotamente situados compreenderam uma imagem orbital do sensor Sentinel-2/MSI. A partir dessa imagem, foram calculados 14 índices de vegetação médios por parcela. Esses índices foram correlacionados o volume por parcela $\left(\mathrm{m}^{3} 0.04 \mathrm{ha}^{-1}\right)$ derivado do inventário. Os índices com a melhor correlação para o volume por parcela $\left(\mathrm{m}^{3} 0.04 \mathrm{ha}^{-1}\right)$ foram o Generalized Difference Vegetation Index (GDVI) e Soil Adjusted Vegetation Index (SAVI) com 0,39 e 0,36, respectivamente. O melhor modelo de regressão ajustado utilizando esses IVs estimou o volume por parcela com $R^{2}$ ajustado de 0,9402 e Syx de 1,44\%. A utilização de índices espectrais gerados a partir de dados do sensor Sentinel-2/MSI possibilitou a estimativa volumétrica do povoamento de Pinus taeda L. Entretanto, vale indicar a realização de novos testes em outras espécies florestais e com sensores de média a alta resolução espacial.

PALAVRAS-CHAVE: Sensoriamento remoto, Stepwise, Índices de vegetação. 


\section{INTRODUCTION}

Forestry activity is related to plantations formed by high quality trees at the end of the rotation. For this, the conditions of the forest must be monitored frequently, through the sampling of biophysical parameters by forest inventory. Variables such as wood volume, basal area and height are essential parameters for the management of forest resources (GUNLU et al., 2014).

Obtaining dendrometric variables such as volume (v), height ( $h$ ) and diameter at breast height ( $\mathrm{dbh}$ ) is associated with carrying out forest inventories, which, depending on the area to be analyzed, become costly and expensive (ALVES et al., 2013) providing the study of alternatives and techniques to facilitate the collection of such data (CANAVESI et al., 2010). In this scenario, Remote Sensing (RS) techniques have become a promising alternative to field-based methods for estimating tree volumes at the plot level (TESFAMICHAEL et al., 2010). Several research have already been conducted to explore the potential of multispectral (DUBE \& MUTANGA, 2015), hyperspectral (HYCZA et al., 2018) and data from active sensors (CHEN et al., 2021).

For the use of RS techniques, medium spatial resolution multispectral images represent a possible alternative due to their wide coverage and availability of free images, in the case of some remote sensors (SARKER \& NICHOL, 2011). Remote sensors such as the Landsat series and the Sentinel-2 satellite constellation comprise viable alternatives due to the ease and availability of data, as well as the great potential explored by other studies, as can be mentioned: Nink et al. (2015), Berra et al. (2016), Santos et al. (2017), Chrysafis et al. (2017), Mura et al. (2018), Pertille et al. (2019), Gonçalves et al. (2019), and Hu et al. (2020).

The wood volume of a forest stand can be estimated by correlating data previously sampled in the field with independent variables, such as vegetation indices derived from orbital images, and by obtaining mathematical equations to specialize the estimates of the desired dependent variable (SANTOS et al., 2017).

Inserted in this theme, the importance of accurate estimates of the timber potential of a forest stand is noted. Thus, correlation analysis between biophysical parameters such as volume with vegetation indices from remote sensors and the use of modeling to adjust regression models must be understood and used in the forest area. A sensor with potential to be explored in these studies comprises the Sentinel-2/MSI satellite mission developed by the European Space Agency (ESA), with a spatial resolution of 10 meters, inclusion of four bands in the red edge band, temporal resolution 5 to 10 days and free data generation (ESA, 2010).

This research aimed to investigate the potential of vegetation indices derived from Sentinel-2/MSI images in the volumetric modeling of a stand of Pinus taeda $\mathrm{L}$. located in Bom Retiro, Santa Catarina State.

\section{MATERIAL AND METHODS}

\section{Study area}

The research was conducted in a forest stand of Pinus taeda L. located in the municipality of Bom Retiro, in the mountainous region of Santa Catarina (Figure 1). The area has an average altitude of 877 meters and the climate is classified by Koppen as $\mathrm{Cfb}$, with temperate climate and mild summer. The average annual temperature is $15.6 \circ \mathrm{C}$. The average annual rainfall is $1386 \mathrm{~mm}$ (ALVARES et al., 2013).

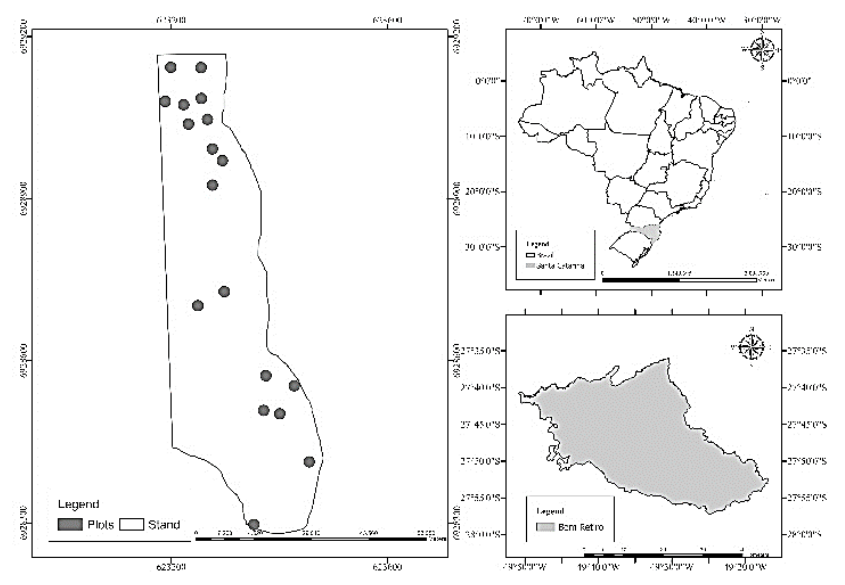

Figure 1. Location of study area.

\section{Field data}

From the random sampling process with the fixed area method, 18 circular plots with a radius of 11.28 meters and $400 \mathrm{~m}^{2}$ were allocated. In all plots, the dbh of all trees was measured with the bra. The height of approximately $10 \%$ of the trees in the plot and in the dominant ones was measured with aid of Vertex Hypsometer. The central coordinate of the plot was obtained with aid of the GPS (Global Positioning System) model Garmin Etrex ${ }^{\circledR}$.

The rigorous cubage was performed by the Smalian method on 25 trees divided into different diameter classes, with a minimum diameter of $21 \mathrm{~cm}$ and a maximum of 50.7 $\mathrm{cm}, 29.7$ in which were measured as stump heights, total heights and the diameter in the positions of $0.07 \mathrm{~m}, 0.7 \mathrm{~m}$, $1.30 \mathrm{~m}, 3.3 \mathrm{~m}, 5.3 \mathrm{~m}$ and so on successively every two meters until the end of the tree. Subsequently, the 
nonlinear Schumacher-Hall model was designed for individual volumetric estimation.

\section{Remote sensing}

Images from the Sentinel-2 satellite were used with the MSI sensor (Multispectral Instrument), with images with 10,20 and 60 meters of spatial resolution, 12 bits of radiometric resolution and 13 spectral bands, with emphasis on the inclusion of red-bands. edge (ESA, 2010).

The image was acquired from the Copernicus Open Access Hub portal, in 2A format, for the date 03/22/2019, orbit 221 and point 79 . The criterion for choosing the images was the absence and/or little coverage of clouds and dates near the installation of the field plots.

The format obtained from the image already included atmospheric corrections and the conversion of digital numbers to radiance at the top of the atmosphere. Thus, the digital image processing involved only the resampling of all bands to 10 meters, a process carried out in a GIS environment (ESRI, 2021). Next, the vegetation indices (VI) described in Table 1 in the processed image were derived:

Subsequently, the plots were georeferenced and delimited in the image, using their central coordinates, obtained via GPS. In a GIS environment, the plot area was reproduced $\left(400 \mathrm{~m}^{2}\right)$. And finally, mean values of vegetation indices per plot were also obtained in a GIS environment (ESRI, 2021).

\section{Volumetric modeling}

The mean values of vegetation indices per plot were statistically evaluated by Pearson's correlation analysis with 95\% significance. After identifying the best correlated VIs with the response variable (volume $\left(\mathrm{m}^{3} 0.04 \mathrm{ha}^{-1}\right)$ ), the regression analysis was used using the Stepwise technique, aiming to estimate the volume of the plot $\left(\mathrm{m}^{3} 0.04 \mathrm{ha}^{-1}\right)$. With the definition of the set of possible predictor variables to be used in the model, the next step was the elimination of redundant or non-significant variables, resulting in a model with the least possible parameters to be estimated to explain the behavior of the response variable. Furthermore, Abadd \& Torres (2002) describe this technique to understand the relationship between the relationship between variables.

To use this technique, two ways of selecting predictor variables for the model derived by stepwise were used: adding variables using the forward method and removing variables using the backward method. The criterion for choosing the variables in this study was the lowest value of the Akaike Information Criterion (AIC).

Table 1. Vegetation indices calculated referring to the stand Pinus taeda $\mathrm{L}$.

\begin{tabular}{|c|c|c|}
\hline VI & Formula & Reference \\
\hline Clgreen & $\frac{\rho \mathrm{NIR}}{\rho \mathrm{RED}}-1$ & $\begin{array}{l}\text { Gitelson et al. } \\
\qquad(2003)\end{array}$ \\
\hline EVI2 & $2,5^{*} \frac{(\rho N I R-\rho R E D)}{\left(\rho N I R+2,4^{*} \rho R E D+1\right)}$ & Jiang et al. (2008) \\
\hline GDVI & $\rho N I R-\rho G R E E N$ & Sripada et al. 2006 \\
\hline GNDVI & $\frac{\rho N I R-\rho G R E E N}{\rho N I R+\rho G R E E N}$ & $\begin{array}{l}\text { Gitelson et al. } \\
\text { (1996) }\end{array}$ \\
\hline IPVI & $\frac{\rho \text { NIR }}{\rho \text { NIR }+\rho \text { RED }}$ & Crippen (1990) \\
\hline MPRI & $\frac{\rho \text { GREEN }-\rho \text { RED }}{\rho \text { GREEN }+\rho \text { RED }}$ & Yang et al. (2008) \\
\hline NDI11 & $\frac{\rho \mathrm{NIR}-\rho \mathrm{SWIR} 1}{\rho \mathrm{NIR}+\rho \mathrm{SWIR} 1}$ & $\begin{array}{l}\text { Hardisky et al. } \\
\qquad(1983)\end{array}$ \\
\hline NDI12 & $\frac{\rho \mathrm{NIR}-\rho \mathrm{SWIR} 2}{\rho \mathrm{NIR}+\rho \mathrm{SWIR} 2}$ & Key et al. (2002) \\
\hline NDVI & $\frac{\rho N I R-\rho \text { RED }}{\rho N I R+\rho \text { RED }}$ & Rouse et al. (1973) \\
\hline NDVIR & $\frac{\rho N I R-\rho R E}{\rho N I R+\rho R E}$ & $\begin{array}{c}\text { Gitelson \& Merzlyak } \\
\text { (1994) }\end{array}$ \\
\hline PSRI & $\frac{\rho \text { NIR }-\rho B L U E}{\rho \text { RED }}$ & $\begin{array}{l}\text { Merzlyak et al. } \\
\qquad(2003)\end{array}$ \\
\hline SAVI & $\frac{(1+L)(\rho N I R-\rho R E D)}{\rho N I R+\rho R E D+L}$ & Huete (1988) \\
\hline SR & $\frac{\rho N I R}{\rho R E D}$ & Jordan (1969) \\
\hline VARI & $\frac{\rho \text { GREEN }-\rho \text { RED }}{\rho \text { GREEN }+\rho \text { RED }-\rho \text { BLUE }}$ & $\begin{array}{l}\text { Gitelson et al. } \\
\qquad(2002)\end{array}$ \\
\hline
\end{tabular}

VI: vegetation index; $\rho$ BLUE: Blue band reflectance; $\rho$ GREEN: Green band reflectance; $\rho R E D$ : Red band reflectance; $\rho N I R$ : Near infrared band reflectance; $\rho S W I R$ : Shortwave infrared band reflectance; $\mathrm{L}$ : constant that minimizes the effects of the soil, used in this study the value of $0.50 ; \gamma=$ slope of the ground line, used in this study the value of $0.50 ; \gamma=$ inclinação da linha de solo; CLgreen: Chlorophyll Index; EVI2: Enhanced Vegetation Index 2; GDVI: Generalized Difference Vegetation Index; GNDVI: Green Normalized Difference Vegetation Index; IPVI: Infrared percentage vegetation index; MPRI: Modified Photochemical Reflectance Index; NDI11: Normalized Difference Infrared Index; NDI12: Normalized Burn Ratio; NDVI: Normalized Difference Vegetation Index; SAVI: Soil Adjusted Vegetation Index; SR: Simple Ratio Vegetation Index; VARI: Visual Atmospheric Resistance Index.

The comparison criteria of the adjusted models were adjusted coefficient of determination (adjusted $R^{2}$ ), standard error of the estimate (Syx), standard error of the estimate in percentage (Syx\%) and graphic analysis of residues following the recommendations of the study by Nicoletti et al. (2016). The values of Akaike Information 
Criterion (AIC) (Equation 1) and Bayesian Information Criterion (BIC) (Equation 2) (KUIPER, 2020) were also considered. The RMSE (Root Mean Squared Error) (Equation 3) was also calculated:

$$
A I C=2 \log (\theta)+2 k
$$

Note: $\log L(\theta)$ : logaritmo da função da máxima verossimilhança; k: número de parâmetros do modelo.

$$
B I C=-2 \log \left(L_{p}\right)+[(p+1)+1] \log (n)
$$

Note: $n$ : number of observations in the sample; $p$ : number of model parameters; Lp: function of the maximum likelihood of the model.

$$
\text { RMSE }=\sqrt{\frac{\sum(y-y i)^{2}}{n}}
$$

Note: y: observed variable; yi: estimated variable; $n$ : number of observations.

\section{RESULTS AND DISCUSSION}

Figure 2 illustrates the descriptive statistics of the dendrometric variables of the studied stand:

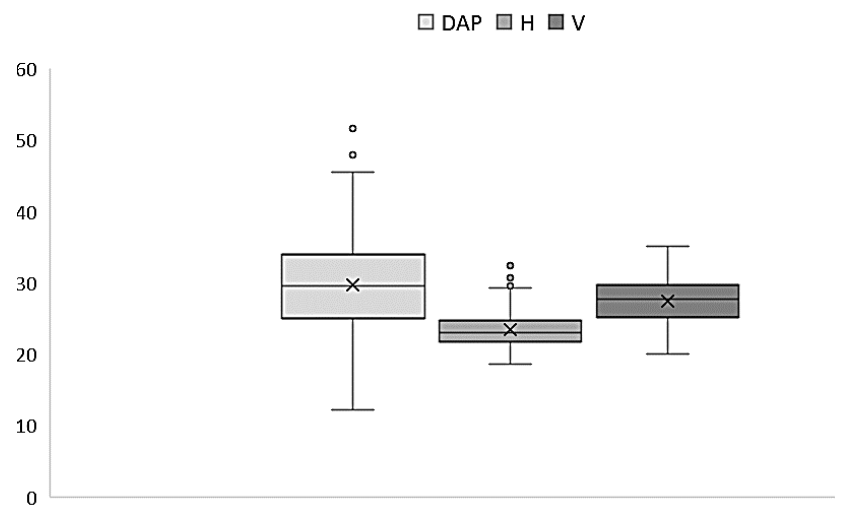

Figure 2. Descriptive statistics of the Pinus taeda L. stand located in Bom Retiro, SC. $m$ which: DBH: diameter at breast height $(\mathrm{cm}) ; \mathrm{H}$ : total height (m); V: volume by plot $\left(\mathrm{m}^{3} 0.04 \mathrm{ha}^{-1}\right)$.

The average vegetation indices by plot and the volume by plot (Table 2) showed a significant positive correlation between them. The GDVI, SAVI and PSRI indices had the highest correlation, while the NDI12, VARI and GNDVI indices had the lowest correlation.

The correlated VIs shows the behavior already described and observed in other research, for using bands in the visible and infrared region. Thus, the IVs demonstrate the antagonistic behavior of the vegetation reflectance in the visible and NIR region (PONZONI \& SHIMABUKURO, 2007). Red, located in the visible region, has lower reflectance. Infrared, on the other hand, has a higher reflectance caused by the multiple scattering of electromagnetic radiation in the different layers of leaves (MYNENI et al., 1995). Another important factor refers to the canopy of the stand, as older plantations tend to have closed canopies, as in the case evaluated. Therefore, the positive correlation found in this study is in line with the statement by Spanner et al. (1990) that closed canopies have positive correlations and negative correlations are found in areas with open canopies.

Table 2. Pearson correlation coefficients between volume by plot $\left(\mathrm{m}^{3} 0.04 \mathrm{ha}^{-1}\right)$ and average vegetation indices by plot for a stand of Pinus taeda L. in Bom Retiro - SC.

\begin{tabular}{cc}
\hline Sentinel-2 & Volume \\
\hline Volume & 1 \\
\hline Clgreen & $0,0882^{*}$ \\
\hline EVI2 & $0,0754^{*}$ \\
\hline GDVI & $0,3962^{*}$ \\
GNDVI & $0,0881^{*}$ \\
\hline IPVI & $0,0739^{*}$ \\
MPRI & $0,0670^{*}$ \\
NDI11 & $0,1346^{*}$ \\
NDI12 & $-0,0444^{*}$ \\
NDVI & $0,0739^{*}$ \\
NDVIR & $0,1831^{*}$ \\
\hline PSRI & $0,2270^{*}$ \\
SAVI & $0,3668^{*}$ \\
SR & $0,0882^{*}$ \\
VARI & $-0,0406^{*}$ \\
\hline
\end{tabular}

*significant at 5\% probability.CLgreen: Chlorophyll Index; EVI2: Enhanced Vegetation Index 2; GDVI: Generalized Difference Vegetation Index; GNDVI: Green Normalized Difference Vegetation Index; IPVI: Infrared percentage vegetation index; MPRI: Modified Photochemical Reflectance Index; NDI11: Normalized Difference Infrared Index; NDI12: Normalized Burn Ratio; NDVI: Normalized Difference Vegetation Index; SAVI: Soil Adjusted Vegetation Index; SR: Simple Ratio Vegetation Index; VARI: Visual Atmospheric Resistance Index

Furthermore, Curran (1986) indicates that leaf reflectance can be affected by soil contribution depending on the leaf area index and the sun and sight geometry. Jensen (2009), on the other hand, considers that variations in the spectral response of vegetation are linked to the percentage of aboveground biomass of the vegetation. Some studies have confirmed that there is a direct relationship between the NIR response and biomassrelated variables, and an inverse relationship between the 
visible responses, particularly in red. Thus, as the plant canopy develops, its reflectance increases in the NIR and its absorptance increases in the red region because of increased photosynthesis.

SAVI also showed a positive correlation in a similar work developed by Pertille et al. (2019). In that research, this VI (obtained from Sentinel-2 images) had a correlation of 0.4968 with the volume of a stand of Pinus taeda L. This means that SAVI was the most sensitive vegetation index to the vegetation conditions and, therefore, it was used to estimate the volume of wood in the stand. This value is related to the conditions of the stand of Pinus taeda $\mathrm{L}$. evaluated at 24 years and with thinning interventions.

Other VIs has already been highlighted in similar studies, such as the research by Chrysafis et al. (2017). The authors identified that IVs derived from a Sentinel-2/MSI image (DVI, EVI and PVI) were significantly positively correlated with the volume of a heterogeneous Mediterranean forest located in northeastern Greece and explain that the use of traditional VIs like these improved the correlation.

The volumetric regression models fitted with the VIs with the highest correlation (GDVI, SAVI and PSRI) demonstrated significant adjustment statistics, with an adjusted coefficient of determination between 0.26 and 0.94 and RMSE between 3.51 and 7.76 (Table 4). The models evaluated in Table 3 were obtained considering the three VIs best correlated with the volume by plot $\left(\mathrm{m}^{3} 0.04\right.$ $\mathrm{ha}^{-1}$ ) considering the techniques of addition or removal of Stepwise variables. This resulted in models with better fit (Stepwise 1) including the three VIs and models with low fit statistics (Stepwise 4 and 5) due to the use of an VI as an independent variable.

Table 3. Fit statistics of the regression models tested using Sentinel- 2 data to estimate the volume by plot $\left(\mathrm{m}^{3}\right.$ $0.04 \mathrm{ha}^{-1}$ ) for a stand of Pinus taeda L. in Bom Retiro-SC.

\begin{tabular}{cccccc}
\hline Model & $\mathbf{R}^{\mathbf{2}}$ aj & Syx (\%) & AIC & BIC & RMSE \\
\hline 1 & 0,94 & 1,44 & 31,6 & 47,6 & 4,49 \\
2 & 0,80 & 1,28 & 74,9 & 86, & 3,51 \\
3 & 0,88 & 1,37 & 62,2 & 75,63 & 3,76 \\
4 & 0,44 & 12,75 & 95,3 & 105,1 & 6,52 \\
5 & 0,26 & 16,59 & 99,8 & 107,1 & 7,76 \\
6 & 0,65 & 5,89 & 85,2 & 97,6 & 4,61
\end{tabular}

$\mathrm{R}^{2}$ aj: adjusted coefficient of determination; Syx (\%): standard error of the estimate in percentage; AIC: Akaike Information Criterion; BIC: Bayesian Information Criterion; RMSE: Root Mean Squared Error.

Another criterion for choosing the best model
(Stepwise 1) is the graphical analysis of the residuals (Figure 3), in which it is possible to see a homogeneous distribution of the residuals in all adjusted models.

\section{Stepwise 1}

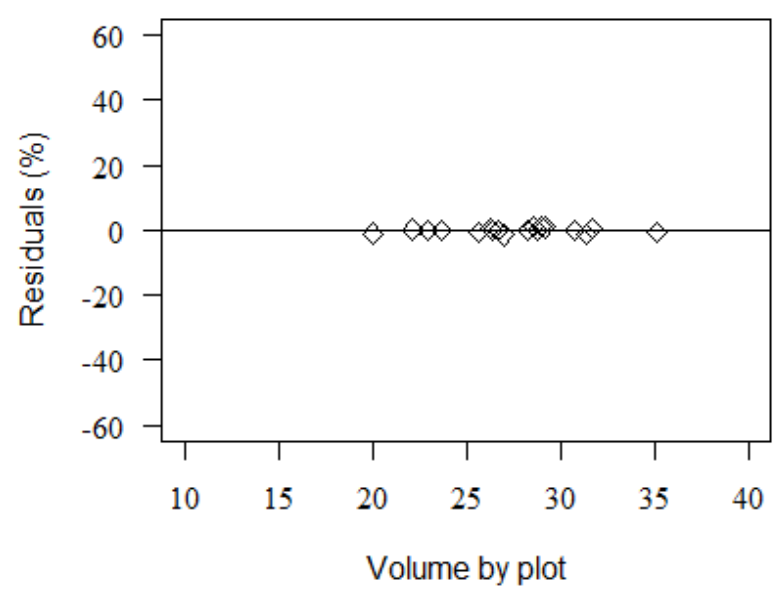

Figure 3. Graphical dispersion of the residues of the best fitted model with Sentinel-2 data in the estimation of volume by plot $\left(\mathrm{m}^{3} 0.04 \mathrm{ha}^{-1}\right)$ of a stand of Pinus taeda L. in Lages - SC.

In Figure 3, it is possible to notice the absence of independence from the errors, one of the presuppositions of the regression analysis in all models. In addition, there were underestimates and overestimates. The model that presented the most reliable volume estimate $\left(\mathrm{m}^{3} 0.04 \mathrm{ha}\right.$ $\left.{ }^{1}\right)$ was the model titled Stepwise 1 , due to the better adjustment statistics (adjusted $\mathrm{R}^{2}$ of 0.94 and lower error standard of the estimate $1.44 \%$ ) and of the best graphic distribution of the residues (Figure 3 ).

Figure 4 compares the studied methods, demonstrating the variation between data obtained by traditional forest inventory methodologies and by Remote Sensing techniques.

\section{Volume Estimates}

$\square$ Inventory $\square$ Sentinel-2

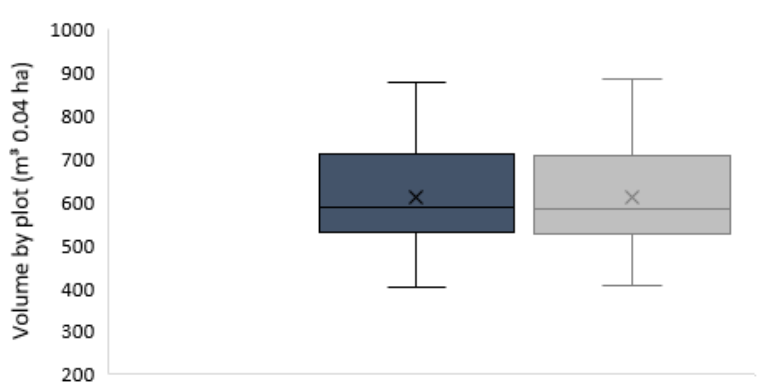

Figure 4. Estimates of the volume by plot $\left(\mathrm{m}^{3} 0.04 \mathrm{ha}^{-1}\right)$ by the evaluated methods. 
Several studies aimed at estimating dendrometric variables and obtaining the volume of forest stands using Sentinel-2/MSI sensor data were found in the literature.

Chrysafis et al. (2017) concluded that the data derived from the Sentinel-2/MSI sensor were slightly superior compared to the Landsat-8/OLI images from the results of the Random Forest regression algorithm that was used to model the relationship between the spectral information inherent to both sensors and forest volume.

Gonçalves et al. (2018) evaluated the use of a set of Sentinel-2 and SRTM data to obtain the wood volume in an area of Seasonal Semideciduous Forest. The authors obtained a model with $\mathrm{R}^{2}$ of 0.65 and RMSE of $20.41 \%$ at fit and 0.56 and RMSE of $26.61 \%$ at validation, using the combined data of MSI and SRTM as predictors.

Orbital images of different spatial resolution have already been used to determine the volume of a stand of Pinus taeda L. in the study by Pertille et al. (2019). Landsat8/OLI and Sentinel-2/MSI data were tested, and the best estimates were made with a regression model using GNDVI, with an adjusted coefficient of determination of 0.51 and standard error of the estimate of $14.74 \%$ for Landsat-8/OLI and 0.46 and standard error of the estimate of $15.20 \%$ using SAVI obtained via Sentinel-2/MSI.

In the current research, we chose to use only one modeling technique (Stepwise). However, recent studies show the gains from the use of other methodologies, especially Machine Learning, as described by $\mathrm{Hu}$ et al. (2020). By using Random Forest (RF) algorithms, Support Vector Regression (SVR) and Multiple Linear Regression (MLR), the authors realized that the RF-derived model presented the best performance, with $\mathrm{R}^{2}$ of $0.91, \mathrm{RMSE}=$ $35.13 \mathrm{~m}^{2} \mathrm{ha}^{-1}, \mathrm{n}=321$ ). The SVR model, on the other hand, presented an $R^{2}$ of 0.54 and RMSE of $65.60 \mathrm{~m}^{3} \mathrm{ha}^{-1}$ and the MLR model ( $R^{2}$ of 0.38 and RMSE of $75.74 \mathrm{~m}^{3} \mathrm{ha}^{-1}$. Thus, the use of RF regression yielded an overall accuracy of $63.87 \%$ compared to the official 2017 forest report for the assessed area.

Neto et al. (2021) evaluated the estimate of the individual volume of Eucalyptus spp. using isolated and joint machine learning techniques, concluding that the Schumacher-Hall and Ensemble models were more precise and accurate in predicting the volume for the data used. The authors also recommend testing this methodology to estimate other variables and other forest species.

\section{CONCLUSION}

The use of spectral indices generated from Sentinel$2 / \mathrm{MSI}$ sensor data allowed the volumetric estimate of the
Pinus taeda L. stand, not revealing significant differences between the volume obtained by forest inventory and by orbital images.

It is worth emphasizing the importance of future tests of this methodology incorporating machine learning in regression techniques and high spatial resolution images.

\section{ACKNOWLEDGMENT}

To FAPESC and to the research group, Management of Forest Resources.

\section{REFERENCES}

ALVARES, C.A. et al. Köppen's climate classification map for Brazil. Meteorologische Zeitschrift, v.22, n.6, p.711-728, 2013.

ALVES, M.V.G. et al. Aplicação de k-nearest neighbor em imagens multispectrais para a estimativa de parâmetros florestais. Floresta, v.43, n.3, p.351-362, 2013.

BERRA, E.F. et al. Comparison of satellite imagery from LISSIII/Resourcesat-1 and TM/ Landsat 5 to estimate stand-level timber volume. Pesquisa Florestal Brasileira, v.36, n.88, p.363373, 2016.

CANAVESI, V. et al. Estimativa de volume de madeira em plantios de Eucalyptus spp. utilizando dados hiperespectrais e dados topográficos. Revista Árvore, v.34, n.3, p.539-549, 2010.

CHEN, L. et al. Improved estimation of forest stand volume by the integration of GEDI LiDAR data and multi-sensor imagery in the Changbai Mountains Mixed Forests Ecoregion (CMMFE), northeast China. International Journal of Applied Earth Observation and Geoinformation, v.100, e102326, 2021.

CHRYSAFIS, I. et al. Estimating mediterranean forest parameters using multi seasonal Landsat $8 \mathrm{OLI}$ imagery and an ensemble learning method. Remote Sensing of Environment, v.199, p.154166, 2017.

CRIPPEN, R. Calculating the vegetation index faster. Remote Sensing Environment, v.34, p.71-73, 1990.

CURRAN, P.J. Principles of Remote Sensing. New York: Logman, 1986.

DUBE, T. et al. Predicting Eucalyptus spp. stand volume in Zululand, South Africa: an analysis using a stochastic gradient boosting regression ensemble with multi-source data sets. International Journal of Remote Sensing, v.36, p.3751-3772, 2015.

ESA - EUROPEAN SPACE AGENCY. GMES Sentinel-2 Mission. 2010. Disponível em: http://esamultimedia.esa.int/docs/GMES/ Sentinel-2/MRD.pdf

ESRI - ENVIRONMENTAL SYSTEMS RESEARCH INSTITUTE. ArCGIS Professional GIS for the desktop, version 10.4.1. 2021. Disponível em: https://support.esri.com/en/Products/Desktop/ 
arcgis-desktop/arcmap/10-8-1\#overview

GITELSON, A.A.; MERZLYAK, M.N. Quantitative estimation of chlorophyll-a using reflectance spectra: Experiments with autumn chestnut and maple leaves. Journal of Photochemistry and Photobiology Biology, v.22, n.3, p.247-252, 1994.

GITELSON, A.A. et al. Use of a green channel in remote sensing of global vegetation from EOS-MODIS. Remote Sensing of Environment, v.58, p.289-298, 1996.

GITELSON, A.A. et al. Assessing carotenoid content in plant leaves with reflectance spectroscopy. Photophysical and Photochemical, v.75, p.272-281, 2002.

GITELSON, A.A. et al. Relationships between leaf chlorophyll content and spectral reflectance and algorithms for nondestructive chlorophyll assessment in higher plant leaves. Journal of Plant Physiology, v.160, p.271-282, 2003.

GONÇALVES, A.F.A. et al. Wood volume estimation in a semidecidual seasonal forest using MSI and SRTM data. Floresta e Ambiente, v.26, e20180379, 2019.

GUNLU, A. et al. Prediction of some stand parameters using pansharpened IKONOS satellite image. European Journal of Remote Sensing, v.47, p.329-342, 2014.

HARDISKY, M. et al. The influences of soil salinity, growth form, and leaf moisture on the spectral reflectance of Spartina Alterniflora Canopies. Photogrammetric Engineering and Remote Sensing, v.49, p.77-83, 1983.

HENRY, M. et al. Estimating Tree Biomass of Sub-Saharan African Forests: A Review of Available Allometric Equations. Silva Fennica, v.45, p.477-569, 2011.

HYCZA, Y. et al. Potential use of hyperspectral data to classify forest tree species. New Zealand Journal of Forestry Science, v.48, n.18, p.1-13, 2018.

$\mathrm{HU}, \mathrm{Y}$. et al. Estimating forest stock volume in Hunan province, China, by integrating in situ plot data, sentinel-2 images, and linear and machine learning regression Models. Remote Sensing, v.12, n.1, p.1-23 2020.

HUETE, A.R. A soil vegetation adjusted index (SAVI). Remote Sensing of Environment, v.25, p.295-309, 1988.

JIANG, Z. et al. Development of a two-band enhanced vegetation index without a blue band. Remote Sensing of Environment, v.112, p.3833-3845, 2008.

JENSEN, J.R. Sensoriamento remoto do ambiente: uma perspectiva em recursos terrestres. São José dos Campos: Parêntese, 2009.

JORDAN, C.F. Derivation of leaf-area index from quality of light on the forest floor. Ecology, v.50, n.406, p.663-666, 1969.

KEY, C.H. et al. The normalized burn ratio and relationships to burn severity: ecology, remote sensing and implementation. Proceedings of the Ninth Forest Service Remote Sensing Applications Conference, 2002.
KUIPER, R. AIC-type Theory-Based Model Selection for Structural Equation Models. Structural Equation Modeling: A Multidisciplinary Journal, 2021.

MERZLYAK, M.N. et al. Application of reflectance spestroscopy for analysis of higher plant pigments. Journal of Virological Methods, n.167, p.140-145, 2003.

MURA, M. et al. Exploiting the capabilities of the Sentinel-2 multi spectral instrument for predicting growing stock volume in forest ecosystems. International Journal of Applied Earth Observation and Geoinformation, v.66, p.126-134, 2018.

MYNENI, R.B. et al. The interpretation of spectral vegetation indexes. IEEE Transactions on Geoscience and Remote Sensing, v.33, n.2, p.481-486, 1995.

NETO, E.M.C. et al. Aprendizado de máquina e regressão linear na estimativa do volume de Eucalyptus na Amazônia oriental. BIOFIX Scientific Journal, v.6, n.1, p.08-14, 2021.

NICOLETTI, M.F. et al. Relação hipsométrica para Pinus taeda L. em diferentes fases do ciclo de corte. Floresta e Ambiente, v.23, n.1, p.80-89, 2016.

NINK, S. et al. Assessing the suitability of future multi and hyperspectral satellite systems for mapping the spatial distribution of norway spruce timber volume. Remote Sensing, v.7, p.12009-12040, 2015.

PERTILLE, C.T. et al. Estimativa do volume de Pinus taeda L. a partir de dados de sensoriamento remoto. Scientia Forestalis, v.47, n.123, p.526-535, 2019.

PONZONI, F.J.; SHIMABUKURO, Y.E. Sensoriamento Remoto no estudo da vegetação. São José dos Campos: Parêntese, 2007.

$R$ CORE TEAM. R. A language and environment for statistical computing. Vienna: R Foundation for Statistical Computing, 2021.

ROUSE, J. W. et al. Monitoring vegetation systems in the great plains with ERTS. Earth Resources Technology Satellite-1 Symposium, p.309-317, 1973.

SANTOS, M.M. et al. Estimativa de parâmetros florestais em área de Cerrado a partir de imagens do sensor OLI Landsat-8. Revista Floresta, v.47, n.1, p.75-83, 2017.

SARKER, L.R.; NICHOL, J.E. Improved Forest Biomass Estimates Using ALOS AVNIR-2 Texture Indices. Remote Sensing of Environment, v.115, p.968-977, 2011.

SPANNER, M.A. et al. Remote Sensing temperate coniferous forest leaf area index: the influence of canopy closure, understory and background reflectance. International Journal of Remote Sensing, v.11, n.1, p.95-111, 1990.

SRIPADA, R. et al. Aerial color infrared photography for determining early in-season nitrogen requirements in corn. Agronomy Journal, v.98, p.968-977, 2006.

TESFAMICHAEL, S. et al. Estimating plot-level tree height and volume of Eucalyptus grandis plantations using small-footprint, 
BIOFIX Scientific Journal v. 7 n. 1 p. 53-60 2022

Pertille, C. T. \& Nicoletti, M. F. et al.

discrete return LiDAR data. Progress in Physical Geography, v.34,

n. 4, p.515-540, 2010.

YANG, Z. et al. Impact of band-ratio enhanced AWIFS image to crop classification accuracy. Pecora - The Future of Land Imaging, p.17, 2008.

Recebido em 22-07-2021

Aceito em 07-09-2021 